\title{
Corporate Entrepreneurship and Business Performance: The Role of External Environment and Organizational Culture: A Proposed Framework
}

\author{
Innocent Otache ${ }^{\mathrm{a}, *}$ \\ Rosli Mahmoodb \\ aOthman Yeop Abdullah Graduate School of Business, Universiti Utara Malaysia,
Tradewinds 3D-115, 06010 Sintok, Kedah, Malaysia
Email: otache2@gmail.com ${ }^{*}$ Corresponding author \\ ${ }^{b}$ School of Business Management, College of Business, Universiti Utara Malaysia, 06010 Sintok, Kedah, Malaysia \\ Email: rosli@uum.edu.my
}

\section{Doi:10.5901/mjss.2015.v6n4s3p524}

\begin{abstract}
This paper proposes a framework which illustrates the moderating and mediating role of external environment and organizational culture in the relationship between corporate entrepreneurship and business performance. The proposed framework is developed based on the review of extant literature. Based on the proposed framework, it is presumed that the effect of corporate entrepreneurship on business performance is dependent on whether external environment and organizational culture are supportive or not.
\end{abstract}

Keywords: corporate entrepreneurship; entrepreneurial orientation; entrepreneurial management; external environment; organizational culture; business performance.

\section{Introduction}

Globally, business environment has become highly dynamic, unpredictable, and competitive (Kuratko, Ireland, \& Hornsby, 2004). This is aided by globalisation, trade liberalisation, and technological developments, particularly in the area of ICT. All these developments have made the world to become a global market, where business organizations compete beyond national boundaries. The scope of competition has been widely expanded, and this creates a lot of challenges for business organizations and managers. Considering these scenarios, it becomes imperative for business organizations to exhibit entrepreneurial behaviour and develop supportive organizational culture in order to survive, gain a competitive advantage over competitors, and achieve superior performance. This is because entrepreneurial activities within existing business organizations are a source of vitality and competitive advantage, which lead to superior business performance (Antoncic \& Hisrich, 2004; Kuratko et al., 2004; Lumpkin \& Dess, 1996; Mohamad, Ramayah, \& Puspowarsito, 2011; Wang, 2008). Entrepreneurial or innovative activities refresh existing business organizations, irrespective of their sizes and nature.

The theory of resource based-view (RBV) states that organizational resources which are valued, rare, and difficult to duplicate and substitute are a source of competitive advantage, which is capable of improving business performance (Barney, 1991). Corporate entrepreneurship (CE), in the light of RBV theory, is acknowledged as a valuable organizational resource, which can give business organizations competitive edges over rivals in the marketplace. Thus, corporate entrepreneurial activities contribute significantly to superior business performance (Lumpkin \& Dess, 2001). Corporate entrepreneurship is a source of competitive and growth strategies. CE rejuvenates and ensures continued existence of an organization. All business organizations, whether new or old, small or large, must be proactive and innovative in their behaviours in order to flourish and compete successfully in the marketplace (Kuratko et al., 2004).

Furthermore, the relationship between corporate entrepreneurship and business performance has been considerably researched (Karacaoglu, Bayrakdaroglu, \& San, 2012; Rauch, Wiklund, Lumpkin, \& Frese, 2009). Entrepreneurship scholars have postulated that corporate entrepreneurship leads to superior business performance. However, a critical review of extant literature reveals that the findings concerning the relationship between corporate entrepreneurship and business performance are inconclusive (Karacaoglu et al., 2013; Rauch et al., 2009). On the one hand, some studies confirmed a positive relationship between corporate entrepreneurship and business performance (Karacaoglu et al., 2012; Mokaya, 2012; Zhang \& Zhang, 2012). On the other hand, other studies affirmed a negative 
CE-performance relationship (Covin, Slevin, \& Schultz, 1994; George, Wood JR, \& Khan, 2001; Shamsuddin, Othman, \& Shahadan, 2012).

Also, there are divergent arguments concerning the impact of corporate entrepreneurship on business performance. Some researchers have argued that the relationship between corporate entrepreneurship (i.e. entrepreneurial orientation) and business performance depends on other strategic business orientations such as market orientation, employee orientation, and learning orientation (Kwak, Jaju, Puzakova, \& Rocereto, 2013; Wang, 2008; Zhao, Li, Lee, \& Chen, 2011). They argued that corporate entrepreneurship will have more positive impact on business performance if it is combined with other strategic business orientations. Other researchers have also posited that the impact of corporate entrepreneurship on business performance depends on a multiplicity of different factors such as organizational structure, external environment, top management support, reward system, organizational culture, and organizational resources and competencies (Kuratko et al., 2004; Rutherford \& Holt, 2007). More so, some other scholars have argued that continuous engagement by business organizations in entrepreneurial activities does not guarantee continuous superior business performance, especially in emerging economies like China, for lack of organizational formalisation, institutional support, and experienced managers (Tang, Tang, Marino, Zhang, \& Li, 2008; Tang \& Tang, 2010).

In view of the inconsistencies and divergent views about corporate entrepreneurship-performance relationship, there is a need to further examine CE-performance relationship by introducing a moderator and a mediator. Researchers have opined that introduction of a moderator or a mediator will help to strengthen or clarify the relationship between a dependent variable and an independent variable (Antoncic \& Hisrich, 2004; Rauch et al., 2009; Wu \& Zumbo, 2007). Contingency theory states that the relationship between variable A and variable B depends on variable $C$ (Rauch et al., 2009). This means that there must be congruence among key organizational and environmental variables for an optimum performance to be achieved. The organizational and external environmental variables must be properly aligned for effective and efficient accomplishment of business objectives. Thus, in order to strengthen or clarify the relationship between corporate entrepreneurship and business performance, two variables are introduced in the proposed framework. The two variables are external environment and organizational culture. External environment is introduced to moderate the relationship between corporate entrepreneurship and business performance whereas organizational culture is introduced to mediate CE-performance relationship.

This implies that the relationship between corporate entrepreneurship and business performance depends on external environmental factors whereas corporate entrepreneurship affects business performance through supportive organizational culture. While external environment has been frequently used by many previous researchers as a moderator of CE-performance relationship, organizational culture is rarely used as a mediator in the study of CEperformance relationship - a gap which this paper narrows.

The objective of this paper, therefore, is to propose a framework that shows the moderating and mediating effects of external environment and organizational culture on the relationship between corporate entrepreneurship and business performance. To achieve this objective, the remaining part of this paper will review relevant literature on corporate entrepreneurship, external environment, organizational culture, and organizational performance with a view to formulating propositions that show the relationships among the variables. Thereafter, a framework that depicts the relationships among the variables will be presented. Finally, the paper will be summarised, conclusions will be drawn, and the implications of the proposed framework will be highlighted.

\section{Literature Review}

\subsection{Corporate Entrepreneurship (CE)}

Corporate entrepreneurship cannot be properly discussed or understood without defining the term entrepreneurship. Entrepreneurship has been variously defined by different authors, from different perspectives. Schumpeter defined entrepreneurship as a process of doing things that are not generally done in the ordinary course of business routine (Kuratko, 2009). Shapero defined it as a type of behaviour which encompasses initiative taking, organization of economic mechanisms to turn resources and situations into practical account, and acceptance of risks of failure (Kuratko, 2009). Ronstadt also defined entrepreneurship as a process of creating wealth by individuals who assume the risks of providing value for some product (Kuratko, 2009). Kuratko (2009) summarizes the definitions given by Schumpeter, Shapero and Ronstadt by defining entrepreneurship as a dynamic process of change, vision and creation which requires an application of passion and energy for the purpose of creating and implementing new ideas and creative solutions. He also added that entrepreneurship encompasses willingness and ability to take calculated or prudent risks; a skill to marshal the required 
resources and develop a solid business plan; and the vision to see or recognize opportunity where others see none.

From the definitions of entrepreneurship given above, it can be implied that corporate entrepreneurship is entrepreneurship within an existing organization, an organizational-level entrepreneurship. Like its parent field (entrepreneurship), corporate entrepreneurship has been variously defined, although it does not have a universally acceptable definition. According to Stevenson and Jarillo (1990), corporate entrepreneurship is defined as the ability of an organization to identify and pursue market opportunities without being inhibited by scarce organizational resources. In agreement with the definition given by Stevenson and Jarillo; Ireland, Kuratko, and Morris (2006) defined CE as a process by which people or a group of people in organizations identify and pursue opportunities without being limited by organizational resources. Corporate entrepreneurship is also defined as a process whereby individuals or a group of individuals in existing organizations create new business or initiate some strategic improvements to existing organizational products, processes, and practices (Sharma \& Chrisman, 1999). Zahra et al (2000) defined CE as organizational activities that are directed at establishing a new business within the organization (Kuratko, Morris, \& Covin, 2011).

A synthesis of the definitions of CE shows that corporate entrepreneurship is concerned with corporate venturing, innovation, and strategic renewal (Antoncic \& Hisrich, 2004; Wang \& Zhang, 2009). While corporate venturing refers to the establishment of a new business within or outside an existing organization, innovation is the introduction of new products or services into new or existing markets. Strategic renewal, on the other hand, involves making some strategic improvements to existing organizational processes and products or services. Corporate entrepreneurship is conceptualized and operationalized in two ways, entrepreneurial orientation (EO) and entrepreneurial management (EM). Entrepreneurial orientation and entrepreneurial management measure the entrepreneurial posture or positioning of an organization as reflected in organizational activities, processes, practices, and administrative routines.

In a bid to define EO, Miller (1983) described an entrepreneurial firm as one that engages in innovative, proactive, and risk-taking acts (Covin \& Wales, 2012). Entrepreneurial orientation is also defined as organizational processes and practices which lead to creation of a new business as characterized by one or a combination of the following dimensions: risk taking, innovativeness, proactiveness, competitive aggressiveness, and autonomy (Covin \& Wales, 2012; Lumpkin \& Dess, 1996). Pearce, Fritz, and Davis (2010) defined EO as a set of distinct but similar behaviours which possess the features of risk taking, innovativeness, proactiveness, competitive aggressiveness, and autonomy (Covin \& Wales, 2012). Entrepreneurial orientation as conceptualized by Miller (1983) is operationalized by Covin and Slevin (1989) as a unidimensional construct with three sub-dimensions, namely risk taking, innovativeness, and proactiveness. They argued that the three dimensions covary with one another. This means that as one dimension increases, the other dimensions will equally increase and vice versa. Furthermore, Lumpkin and Dess (1996) indentified two dimensions in addition to the three dimensions identified by Miller/Covin and Slevin, thereby bringing the dimensions of EO to five. The two dimensions added by Lumpkin and Dess are: autonomy and competitive aggressiveness. Contrary to Miller/Covin and Slevin's proposition that EO is a unidimensional construct and that its dimensions covary, Lumpkin and Dess looked at EO as a multidimensional construct and concluded that the dimensions of EO do not covary. They argued that the dimensions of EO vary independently with business performance, depending on how supportive organizational and environmental variables are. Risk taking is the willingness to commit own or borrowed resources to a venture or project without having assurance of making profit. Innovativeness refers to the introduction of new products, processes, or making some strategic improvements to existing products or processes. Proactiveness is a situation where an organization anticipates opportunities and organizes resources for exploitation of the identified opportunities before other organizations notice the presence of such opportunities. Autonomy refers to a situation where employees or a group of employees are given freedom to take initiatives in exploring and exploiting identified opportunities without being obstructed by bureaucratic processes. Competitive aggressiveness refers to the desire of an organization to outperform others by changing its competitive strategies or techniques which are reflected in the ways resources are deployed.

In order to establish a link between entrepreneurship and corporate entrepreneurship, Stevenson and Jarillo (1990) defined entrepreneurship management as the ability of an organization to identify and pursue market opportunities without being inhibited by limited organizational resources. They described corporate entrepreneurship as a management practice that is opportunity-based, rather than resource-based. On the basis of Stevenson and Jarillo's definition of EM; Brown, Davidsson, and Wiklund (2001) operationalized EM as a construct with six dimensions, namely strategic orientation, resource orientation, management structure, reward philosophy, growth orientation, and entrepreneurial culture. Strategic orientation refers to a situation where opportunities are first identified and resources to exploit them are marshalled. It simply means opportunity perception precedes strategies for exploiting the opportunity. Resource orientation refers to the importance of resources in the exploitation of opportunities. According to Stevenson and Jarillo, for promoter organizations, opportunities are maximized while resources to exploit opportunities are minimized. In the 
same vein, for trustee organizations, opportunities are carefully analyzed to ascertain the risks involved before investing resources. This is because once the decision to invest is taken; it will be difficult to be reversed. Management structure means that organizational structure should be structured in a way that an organization will be able to access the resources it does not own. It also means that organizational structure should be flexible so that individuals or groups within the organizations should be able to pursue identified opportunities to fruition without being obstructed by bureaucracies. Reward philosophy means that employees' rewards should be based on contributions to value creation. Growth orientation means that all organizations desire to grow. However, while promoter organizations desire to grow speedily, trustee organizations desire to grow slowly. Entrepreneurial culture means that employees should be encouraged to be creative and innovative in order for the organization to behave entrepreneurially.

Although Brown et al., (2001) argued that the dimensions of entrepreneurial orientation and entrepreneurial management partly overlap, empirical findings show that organizations benefit more for being entrepreneurially disposed if they are also entrepreneurial in their management styles (Gurbuz \& Aykol, 2009). As pointed out at the Introduction section, several studies have been conducted on CE-performance relationship. However, existing empirical findings show inconclusiveness. This means CE-performance relationship needs to be further investigated. Thus, the following proposition is developed.

Proposition 1: There is significant relationship between corporate entrepreneurship and business performance

\subsection{External Environment as a Potential Moderator}

Generally, business environment refers to forces, factors, or institutions which influence business activities and performance (Kumar, Subramanian, \& Yauger, 1998; Nasiripour, Raeissi, \& Hosseini-Fahraji, 2012; Sul, 2002; Ting, Wang, \& Wang, 2012). It is divided into two, namely internal environment and external environment. While the internal environment is controllable, the external environment is uncontrollable. Although the internal environment is important in business planning and decision-making processes, but of more importance is the external environment which organizations and managers cannot control. External environment refers to forces outside the organization which exert uncontrollable influences on business activities and performance. The impact of the external environment is often examined through its various dimensions. The dimensions of external environment that are usually examined include dynamism, hostility, munificence and complexity (Sul, 2002). External environmental dynamism refers to the unpredictability of the environment as a result of frequent changes while environmental hostility refers to stiff competition that exists among organizations that operate in the same or related industry. Environmental complexity refers to varied and complex information that an organization needs to thrive in an environment. Environmental munificence refers to the presence of opportunities in the environment and availability of resources to exploit available opportunities (Rosenbusch, Rauch, \& Bausch, 2011). Another important dimension of external environment which is also considered is the industry life-cycle stages. Industry life-cycle stages refer to the states of the industry, whether it is emerging, growing, or maturing. Overall, the dimensions of external environment exert different influences on business activities and performance.

Business organizations are not operated in a vacuum. A business organization is described as an open system which interacts with its external environments symbiotically (Racelis, 2010). In other words, business organization benefits from its environment and vice versa. External environment provides opportunities for business organizations to exploit. Also, resources to explore and exploit available opportunities are provided by the external environment. Thus, the availability or otherwise of these opportunities and resources determine the success or failure of business organizations. External environment, therefore, is regarded as an antecedent to corporate entrepreneurship and business performance. Available empirical findings show that external environment has both direct and indirect impact on entrepreneurial activities and business performance (Awang et al., 2009; Covin \& Slevin, 1991; Wiklund \& Shepherd, 2005). Existing literature reveals that business organizations benefit more for engaging in entrepreneurial activities if business environment is highly dynamic and competitive (Covin \& Slevin, 1989, 1991; Ireland et al., 2006). The favourableness or otherwise of external environment determines the impact of corporate entrepreneurial activities on business performance. Therefore, considering the impact of external environment on business activities and performance, the following proposition is developed:

Proposition 2: The relationship between corporate entrepreneurship and business performance is moderated by external environment.

\subsection{Organizational Culture as a Potential Mediator}

Organizational culture is one of the internal organizational variables that have impact on business activities and 
performance (Covin \& Slevin, 1991). Schein defined organizational culture as a set of basic assumptions, values, norms, and artefacts which are shared by members of an organization and define how an organization functions (Geldenhuys, 2006). Organizational culture is also defined as the perception of organizational members regarding how organizational work should be performed (Van den Berg \& Wilderom, 2004). Organizational culture influences every part of an organizational life. It affects the behaviours of an organization and organizational members. It also affects how organizational members relate with one another within the organization and how they relate with people outside the organization such as customers, suppliers, and other organizations. Thus, supportive organizational culture is needed for an organization to undertake certain activities and improve its performance. Extant literature shows that entrepreneurial, adaptive, and innovative cultures are a sources of competitive advantage and also contribute to improved business performance and effectiveness (Nazir \& Lone, 2008; Rose, 2008). Thus, corporate entrepreneurship affects business performance through entrepreneurial, adaptive, and innovative cultures.

Organizational culture is a multidimensional concept. There are different types of organizational culture. This means that business organizations possess or develop different cultures. Deshpande and Farley (1999) classified organizational culture as entrepreneurial culture, competitive culture, consensual culture, and bureaucratic culture. Also, Cameron and Freeman (1991) categorized organizational culture into adhocracy culture, clan culture, market culture, and hierarchy culture. Wallach (1983) equally classified organizational culture as supportive, innovative, and bureaucratic. Accordingly, given the influence of organizational culture on business activities and performance, the following proposition is developed:

Proposition 3: The relationship between corporate entrepreneurship is mediated by organizational culture.

\section{Corporate Entrepreneurship, External Environment, Organizational Culture, and Organizational Performance}

One of the objectives of a business organization is to improve its performance. Performance could be in terms of profitability, market share, growth, or overall business performance. For any business organization to improve its performance, it must consciously undertake certain activities, exhibit certain behaviours, and align itself with external environmental dictates. Available literature shows that entrepreneurial activities such as risk-taking, innovativeness, proactiveness, autonomy, and competitive aggressiveness have positive relationship with profitability, market share, growth, and overall business performance (Barringer \& Bluedorn, 1999; Bhardwaj \& Momaya, 2006; Covin \& Slevin, 1991; Hameed \& Ali, 2011; Ireland et al., 2006; Lassen, Gertsen, \& Riis, 2006; Lumpkin \& Dess, 1996; Odumeru, 2013; Olakitan \& Charles, 2012). A business organization needs to be innovative, proactive, risk tolerant, and competitively aggressive. It must also adopt a flexible structure in order to improve its performance.

In addition, for a business organization to undertake entrepreneurial activities and improve its performance, it must possess or exhibit supportive organizational cultures. Organizational culture affects business activities and performance (Chuang, Morgan, \& Robson, 2012; Nazir \& Lone, 2008). It also affects organizational behaviours and determines how an organization relates with its external environment. In this paper, it is argued that for an organization to undertake entrepreneurial activities and improve its performance, it must possess entrepreneurial culture. Entrepreneurial culture requires that a business organization should be creative, innovative, and must not be averse to risk-taking. Also, learning and adaptive cultures are necessary for corporate entrepreneurial activities to impact positively on business performance. More so, organizational culture of change and innovation is necessary for entrepreneurial activities to thrive (Ireland et al., 2006). It is argued that organizational culture must support risk-taking, proactiveness, and innovativeness for a business organization to behave entrepreneurially (Covin \& Slevin, 1991).

Furthermore, external environmental factors affect business activities and performance. In other words, business activities and performance are dependent on external environmental factors. External environmental factors play an important role in business planning and decision-making. In this paper, it is proposed that CE-performance relationship is contingent on external environment. External environment has both direct and indirect effects on business activities and performance (Gaur, Vasudevan, \& Gaur, 2011; Sebigunda, 2013; Ting et al., 2012). As pointed out earlier, it is argued that entrepreneurial activities will have more positive impact on business performance if external environment is highly dynamic and competitive (Covin \& Slevin, 1989, 1991; Miller, 1983). 


\section{Proposed Framework}

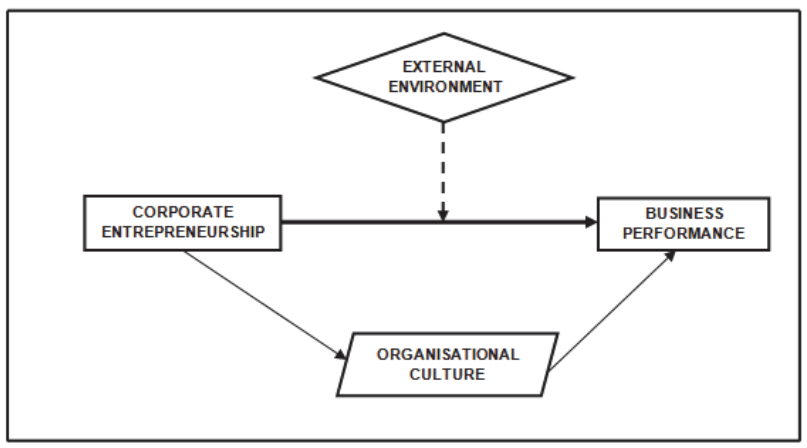

Figure 1. Proposed Framework

Figure 1 shows the proposed relationships among the variables examined in this paper. In the proposed framework, the thick line illustrates the direct relationship between corporate entrepreneurship and business performance. This means that corporate entrepreneurship is presumed to have a direct impact on business performance. The dotted line shows the moderating effect of external environment on the relationship between corporate entrepreneurship and business performance. It implies that corporate entrepreneurship-performance relationship is dependent on external environment. It also means that external environment affects both corporate entrepreneurship and business performance. The thin line depicts the mediating role of organizational culture in CE-performance relationship. It means corporate entrepreneurship affects business performance through organizational culture. Put differently, organizational culture has a relationship with both corporate entrepreneurship and business performance.

\section{Methodology}

As a conceptual paper, it reviewed both theoretical and empirical literature, specifically on corporate entrepreneurship, external environment, organizational culture, and organizational performance. In order to achieve the objective of this paper, which is to propose a framework that illustrates the moderating and mediating effects of external environment and organizational culture on the relationship between corporate entrepreneurship and business performance, related previous articles were collated, reviewed, and synthesized.

\section{Conclusions and Implications}

This paper proposes a framework which illustrates the moderating and mediating effects of external environment and organizational culture on the relationship between corporate entrepreneurship and business performance. It is assumed that the effect of corporate entrepreneurship on business performance is dependent on supportive external environmental factors and organizational cultures. The implication is that business organizations will benefit more for undertaking entrepreneurial activities if environment is dynamic and competitive. Also, business organizations will benefit for behaving entrepreneurially if the environment which they operate in presents opportunities for exploitation and resources for exploiting the opportunities. The framework also implies that for business organizations to be entrepreneurially inclined, supportive cultures are required. This means that business organizations need to possess and continually develop entrepreneurial, innovative, and adaptive cultures if optimum performance must be achieved through entrepreneurial activities. The practical implication of this proposed framework is that business managers must be innovative, proactive, and risk-tolerant if their organizations must gain a competitive advantage and achieve superior performance. It also implies that for business organizations to behave entrepreneurially, the managers themselves must be entrepreneurial in their thinking and behaviours. This is because it is the entrepreneurial behaviours of employees (managers inclusive) that translate into organizational entrepreneurial behaviours. After all, creative and innovative ideas emanate from people, the employees of the organization. 


\section{References}

Antoncic, B., \& Hisrich, R. D. (2004). Corporate entrepreneurship contingencies and organizational wealth creation. Journal of Management Development, 23(6), 518-550. doi:10.1108/02621710410541114

Awang, A., Khalid, S. A., Yusof, A. A., Kassim, K. M., Ismail, M., Zain, R. S., \& Madar, A. R. S. (2009). Entrepreneurial orientation and performance relations of Malaysian Bumiputera SMEs: The impact of some perceived environmental factors. International Journal of Business and Management, 4(9), 84-96.

Barney, J. (1991). Firm resources and sustained competitive advantage. Journal of Management, 17(1), 99-120. Retrieved from http://jom.sagepub.com/content/17/1/99.short

Barringer, B. R., \& Bluedorn, A. C. (1999). The relationship between corporate entrepreneurship and strategic management. Strategic Management Journal, 444, 421-444.

Bhardwaj, B. R., \& Momaya, K. (2006). Role of organizational flexibility for corporate entrepreneurship: Case study of FedEx corporation. Global Journal of Flexible Systems Management, 7(1\&2), 37-44.

Brown, T. E., Davidsson, P., \& Wiklund, J. (2001). An operationalization of Stevenson's conceptualization of entrepreneurship as opportunity-based firm behavior. Strategic Management Journal, 22(10), 953-968. doi:10.1002/smj.190

Cameron, K. S., \& Freeman, S. J. (1991). Cultural congruence, strenght, and type: Relationships to effectiveness. Research in Organnisational Change and Development, 5, 23-58.

Chuang, F.-M., Morgan, R. E., \& Robson, M. J. (2012). Clan culture, strategic orientation and new product performance in Chinese marketing ventures: An exploration of main and moderating effects. Journal of Strategic Marketing, 20(3), $267-286$. doi:10.1080/0965254X.2011.643914

Covin, J. G., \& Slevin, D. P. (1989). Strategic management of small firms in hostile and benign environments. Strategic Management Journal, 10(March), 75-87.

Covin, J. G., \& Slevin, D. P. (1991). A conceptual model of entrepreneurship as firm behaviour. Entrepreneurship Theory and Practice, 16(1), 7-25.

Covin, J. G., Slevin, D. P., \& Schultz, R. L. (1994). Implementing strategic missions: Effective strategic, structural and tactical choices. Journal of Management Studies, 31(4), 481-505.

Covin, J. G., \& Wales, W. J. (2012). The measurement of entrepreneurial orientation. Entrepreneurship Theory and Practice, 36(4), 677702. doi:10.1111/j.1540-6520.2010.00432.x

Deshpande, R., \& Farley, J. U. (1999). Executive insights: Corporate culture and market orientation: comparing Indian and Japanese firms. Journal of International Marketing, 7(4), 111-127.

Gaur, S. S., Vasudevan, H., \& Gaur, A. S. (2011). Market Orientation and manufacturing performance of Indian SMEs: moderating role of firm resources and environmental factors. European Journal of Marketing, 45(7/8), 1172-1193. doi:10.1108/03090561111137660

Geldenhuys, T. (2006). Organizational culture as a predictor of performance: A case study in Liberty Life. Unpublished master's thesis, University of Pretoria.

George, G., Wood JR, R. D., \& Khan, R. (2001). Networking strategy of boards: Implications for small and medium-sized enterprises. Entrepreneurship \& Regional Development, 13(1), 269-286. doi:10.1080/0898562011005811

Gurbuz, G., \& Aykol, S. (2009). Entrepreneurial management, entrepreneurial orientation and Turkish small firm growth. Management Research News, 32(4), 321-336. doi:10.1108/01409170910944281

Hameed, I., \& Ali, B. (2011). Impact of entrepreneurial orientation, entrepreneurial management and environmental dynamism on firm's financial performance. Journal of Economics and Behavioural Studies, 3(2), 101-114.

Ireland, R. D., Kuratko, D. F., \& Morris, M. H. (2006). A health audit for corporate entrepreneurship: Innovation at all levels: Part I. Journal of Business Strategy, 27(1), 10-17. doi:10.1108/02756660610640137

Karacaoglu, K., Bayrakdaroglu, A., \& San, F. B. (2012). The impact of corporate entrepreneurship on firms' financial performance: Evidence from Istanbul stock exchange firms. International Business Research, 6(1), 163-176. doi:10.5539/ibr.v6n1p163

Kumar, K., Subramanian, R., \& Yauger, C. (1998). Examining the market orientation- performance relationship : A context-specific study. Journal of Management, 24(2), 201-234.

Kuratko, D. F. (2009). Introduction to entrepreneurship. Canada: South-Western Cengage Learning.

Kuratko, D. F., Ireland, R. D., \& Hornsby, J. S. (2004). Corporate entrepreneurship behaviour among managers: A review of theory, research, and practice. Advances in Entrepreneurship, Firm Emergence and Growth, 7(04), 7-45.

Kuratko, D. F., Morris, M. H., \& Covin, J. G. (2011). Corporate innovation \& entrepreneurship. Canada: South-Western Cengage Learning.

Kwak, H., Jaju, A., Puzakova, M., \& Rocereto, J. F. (2013). The connubial relationship between market orientation and entrepreneurial orientation. The Journal of Marketing Theory and Practice, 21(2), 141-162. doi:10.2753/MTP1069-6679210202

Lassen, A. H., Gertsen, F., \& Riis, J. O. (2006). The nexus of corporate entrepreneurship and radical innovation. Creativity and Innovation Management, 15(4), 359-372. doi:10.1111/j.1467-8691.2006.00406.x

Lumpkin, G. T., \& Dess, G. G. (1996). Clarifying the entrepreneurial orientation construct and linking it to performance. Academy of Management Journal, 21(1), 135-172.

Lumpkin, G. T., \& Dess, G. G. (2001). Linking two dimensions of entrepreneurial orientation to firm performance: The moderating role of environment and industry life cycle. Journal of Business Venturing, 16(01), 429-451.

Miller, D. (1983). The correlates of entrepreneurship in three types of firms. Management Science, 29(7), 770-791. 
Mohamad, O., Ramayah, T., \& Puspowarsito, H. (2011). Corporate entrepreneurship and firm performance: The role of business environment as a moderator. The IUP Journal of Management Research, X(3), 7-27.

Mokaya, S. O. (2012). Corporate entrepreneurship and organizational performance: Theoretical perspectives, approaches and outcomes. International Journal of Arts and Commerce, 1(4), 133-143.

Nasiripour, A. A., Raeissi, P., \& Hosseini-Fahraji, H. (2012). Environmental dimensions and features affecting organizational entrepreneurship development in Iranian public hospitals. Journal of Hospital Administration, 2(1), 88-102. doi:10.5430/jha. v2n1p88

Nazir, N. A., \& Lone, M. A. (2008). Validation of Denison's model of organizational culture and effectiveness in the Indian context. The Journal of Business Perspective, 12(1), 49-58.

Odumeru, J. A. (2013). Innovation and organizational performance. Kuwait Chapter of Arabian Journal of Business and Management Review, 2(12), 18-22.

Olakitan, O., \& Charles, T. (2012). The role of entrepreneurial orientations on the perceived performance of small and medium-scale enterprises (SMEs) in Nigeria. International Business and Management, 5(2), 148-154. doi:10.3968/j.ibm.1923842820120 502.1130

Racelis, A. D. (2010). The influence of organizational culture on the performance of Philippine banks. Social Science Diliman, 6(2), 2949.

Rauch, A., Wiklund, J., Lumpkin, G. T., \& Frese, M. (2009). Entrepreneurial orientation and business performance: An assessment of past research and suggestions for the future. Entrepreneurship Theory and Practice, 33(3), 761-787. doi:10.1111/j.1540$6520.2009 .00308 . x$

Rose, R. C. (2008). Organizational culture as a root of performance improvement: Research and recommendations. Comtemporary Management Research, 4(1), 43-56.

Rosenbusch, N., Rauch, A., \& Bausch, A. (2011). The mediating role of entrepreneurial orientation in the task environment-performance relationship: A meta-analysis. Journal of Management, 39(3), 633-659. doi:10.1177/0149206311425612

Rutherford, M. W., \& Holt, D. T. (2007). Corporate entrepreneurship: An empirical look at the innovativeness dimension and its antecedents. Journal of Organizational Change Management, 20(3), 429-446. doi:10.1108/09534810710740227

Sebigunda, E. N. (2013). How does investment climate and business environment impact firms' efficiency in a post-conflict setting? Evidence from democratic republic of Congo. International Journal of Business and Management, 8(10), $169-185$. doi:10.5539/ijbm.v8n10p169

Shamsuddin, S., Othman, J., \& Shahadan, M. A. (2012). The dimensions of corporate entrepreneurship and the performance of established organization. ACRN Journal of Entrepreneurship Perspectives, 1(2), 111-131.

Sharma, P., \& Chrisman, J. J. (1999). Toward a reconciliation of the definitional issues in the field of corporate entrepreneurship. Entrepreneurship Theory and Practice, 23(3), 11-27.

Stevenson, H. H., \& Jarillo, J. C. (1990). A paradigm of entrepreneurship: Entrepreneurial management. Strategic Management Journal, 11, 17-27. doi:10.1007/3-540-48543-0 7

Sul, H. (2002). An exploratory model of the relationships among the external environment, entrepreneurial strategy, mechanistic-organic structure, and financial performance of restaurant franchisors from the perspective of franchisees. Unpublished doctoral thesis, Virginia Polytechnnic Institute and State University.

Tang, J., Tang, Z., Marino, L. D., Zhang, Y., \& Li, Q. (2008). Exploring an inverted u-shape relationship between entrepreneurial orientation and performance in Chinese ventures. Entrepreneurship Theory and Practice, 32(1), 219-239.

Tang, Z., \& Tang, J. (2010). Entrepreneurial orientation and SME performance in China's changing environment: The moderating effects of strategies. Asia Pacific Journal of Management, 29(12), 409-431. doi:10.1007/s10490-010-9200-1

Ting, H., Wang, H., \& Wang, D. (2012). The moderating role of environmental dynamism on the influence of innovation strategy and firm performance. International Journal of Innovation, Management and Technology, 3(5), 13-16. doi:10.7763/IJIMT.2012.V3.288

Van den Berg, P. T., \& Wilderom, C. P. M. (2004). Defining, measuring, and comparing organizational cultures. Applied Psychology, 53(4), 570-582. doi:10.1111/j.1464-0597.2004.00189.x

Wallach, E. J. (1983). Individuals and organizations: The cultural match. Training and Developmnt Journal, 12, 29-36.

Wang, C. L. (2008). Entrepreneurial orientation, learning orientation, and firm performance. Entrepreneurship Theory and Practice, $44(0), 635-657$.

Wang, Y., \& Zhang, X. (2009). Operationalization of corporate entrepreneurship and its performance implications in China: An empirical study. Journal of Chinese Entrepreneurship, 1(1), 8-20. doi:10.1108/17561390910916859

Wiklund, J., \& Shepherd, D. (2005). Entrepreneurial orientation and small business performance: A configurational approach. Journal of Business Venturing, 20(1), 71-91. doi:10.1016/j.jbusvent.2004.01.001

Wu, A. D., \& Zumbo, B. D. (2007). Understanding and using mediators and moderators. Social Indicators Research, 87(3), $367-392$. doi:10.1007/s11205-007-9143-1

Zhang, Y., \& Zhang, X. (2012). The effect of entrepreneurial orientation on business performance: A role of network capabilities in China. Journal of Chinese Entrepreneurship, 4(2), 132-142. doi:10.1108/17561391211242744

Zhao, Y., Li, Y., Lee, S. H., \& Chen, L. B. (2011). Entrepreneurial orientation, organizational learning, and performance: Evidence from China. Entrepreneurship Theory and Practice, 35(2), 293-317. doi:10.1111/j.1540-6520.2009.00359.x 